\section{ESTRATÉGIA DE EMPRESA}

de FRANCISCO GOMES DE MATOS

Săo Paulo: Makron Books, 1993, 434 p.

por Patrícia Amélia Tomei, Professora do

Departarmento de Administraçăo da PUC-RJ.

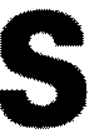
abemos hoje, mais do que nunca, que a qualidade, a produtividade e a competitividade de uma empresa não são tarefas a penas para especialistas. Atualmente, todos os executivos precisam enfrentar esses imperativos de gestăo dinâmica. A busca de bons desempenhos e resultados empresariais deixou de ser internalizada pelos elementos da organizaçâo como um objetivo principal e exclusivo da alta gerência. Passou a ser, entăo, uma filosofia necessária ao funcionamento de toda uma estrutura preocupada em alcançar o sucesso efetivo. Sucesso que é comemorado à medida que a estratégia de empresa é "consistentemente conscientizada e coerentemente exercida".

No livro Estratégia de empresa, o autor Francisco Gomes de Matos apresenta uma exposição clara e interessante, que fornece subsídios para que essa prática cotidiana se torne realidade em todos os níveis da organizaçăo.

O autor, com a experiência de anos como consultor de grandes empresários e "braço direito" na conduçăo dos seus negócios, consegue absorver e transmitir, através de sua obra, os denominadores comuns das atividades empresariais, reavaliando os conceitos-chave de administrar e reforçando, sem demagogia educacional, a busca da boa teoria e da boa reflexão como peça fundamental na integraçăo e renovação empresarial precedendo ações gerenciais improvisadas e soluções imediatistas.

O texto é muito rico em evidenciar a complexidade do fenômeno organizacional com todos os seus paradoxos e desafios, respeitando a sua pluralidade e necessidade de integraçăo.

A conexão teoria e prátíca ê elaborada pelo autor com base na sinergia de quatro dimensões fundamentais para um modelo empresarial de excelência: a profissiona lizaçăo, a descentralizaçăo, a vișâo pró-ativa e a dimensăo humana.

$\mathrm{Na}$ abordagem da profissionalização, o autor destaca a importância de um balanço situacional que operacionaliza o conceito de globalização visto no nível do individuo e do profissional, pincelando um dos aspectos mais importantes e complexos na gerência organizacional: a formação de Recursos Humanos multi-especialistas, com uma visão de sua área e do todo organizacional, gerenciando os "feudos de poder" $\mathrm{e}$ fugindo da competição empresarial predatória e canibalesca.

Nesse sentido, $\hat{e}$ imprescindivel enfatizarmos a riqueza conceitual que embasa o conceito de liderança numa empresa profissionalizada: nesse tipo de organização, não cabem "heróis" e "mitos" pessoas individualistas e brilhantes que dificilmente podem ser imitadas e que,

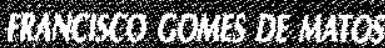
ESTRATEGIA DE EMPRESA com suas atitudes onipotentes, constituem solos férteis para represálias destrutivas e desafiadoras e para uma busca incessante dos seus "pés de barro". Numa empresa profissionalizada, temos espaço para o surgimento de lideranças que tragam a inovação e a criatividade e que negociem com seus seguidores suas crenças e valores para que a equipe promova a gerência da cultura e a mudança organizacional.

Na dimensão de empresa descentralizada, o autor define o conceito de visão estratégica, encarando-a como uma coerente e poderosa maneira de estabelecer o que queremos atingir nos negócios. Em tempos de incerteza e dificuldades, a visão estratégica é vital para estabelecer direçōes.

Na dimensão da empresa moderna, o autor enfatiza a visão organizacional pró-ativa, abordando a "desadministração" da inovaçăo através da análise da idéia de que o "novo", por si só, não sígnifica "algo melhor". Nesse sentido, o autor nos apresenta a importância de se distinguir entre a modernidade e o "novidadesco", conceitos comumente confundidos nas empresas e vendidos através de merchandising imediatista, com embalagens simplistas que näo oferecem condiçóes de um marketing de conteúdo.

Por fî̀, na dimensão empresa humana, 0 autor destaca o papel do indivíduo para a organizaçấo "humanizante" $\mathrm{e}$ "humanizadora" em contínua renovação e retoma a questăo da equipe, da liderança e da participaçầo como focos centrais para uma estratégia de empresa.

Resta-nos salientar que o texto foi escrito basicamente como um relato da ótica organizacional vivenciada pelo autor, sem uma preocupação com o rigor acadêmico e a riqueza bibliográfica de citaçöes. Se, por um lado, isso pode restringir a profundidade conceitual do livro, por outro, proporciona ao leitor um texto agradável, acessivel, recomendado principalmente para profissonais, gerentes ou alunos de pós-graduação que precisam aumentar seu ferramental na gestão de uma empresa. 